\title{
Venous Vascular System of the Mammary Gland in the Buffalo Cow - Morphological Aspects -
}

\author{
Aurel DAMIAN ${ }^{1}$, Antonia SOCACIU ${ }^{1}$, Ioana CHIRILEAN ${ }^{1}$, Florin STAN ${ }^{1}$, Alexandru GUDEA ${ }^{1}$, Cristian \\ DEZDROBITU $^{1}$, Flaviu TUNS ${ }^{1}$, Cristian MARTONOS ${ }^{1}$, Melania CRIŞAN ${ }^{1 *}$, Irina IRIMESCU ${ }^{1}$ \\ ${ }^{1}$ Department of Comparative Anatomy. University of Agricultural Sciences and Veterinary Medicine of \\ Cluj-Napoca, Calea Motilor no. 3-5, 400372, Cluj-Napoca, Romania. \\ *Corresponding author: catedra1mv@yahoo.com
}

Bulletin UASVM Veterinary Medicine 72(2) / 2015,

Print ISSN 1843-5270; Electronic ISSN 1843-5378

DOI:10.15835/buasvmcn-vm: 11412

\begin{abstract}
Considering the clinical benefits derived from the extensive morphological data existing in relation to the vascularisation of the udder in various milk cow breeds, our study focused on assessing the venous vascularisation of the udder in buffalo cows. Ten adult female buffalo cow udders were sampled, their vascularisation highlighted by arterial injection of a coloring agent, then fixed in a $2 \%$ formalin solution for 24 hours. The venous vascular system was identified by stratigraphic dissection under a magnifying glass and examined. We have identified common venous trunks for the homolateral anterior and caudal quarters and perforating veins going through the median septum. In 7 out of 10 examined udders, teat and parenchyma veins merged into a venous circle for each caudal quarter, both of them merging caudally with the greater venous circle at the base of the udder. 5 out of 10 samples also presented secondary venous circles around each anterior quarter. The results of the present study indicate a proportionally better developed venous vascularisation of the caudal quarters in the buffalo cow, correlated with a higher milk production at this level; a superior number of veins and a higher occurrence of venous circles at this level illustrate this aspect. However, the udder presents a unified venous drainage, as superficial veins of homolateral quarters merge, and the median suspensory ligament is traversed by perforating veins.
\end{abstract}

Keywords: buffalo cow, morphology, udder, venous vascular system

\section{INTRODUCTION}

According to overview studies such as that of Nanda and Nakao (2003), buffalos (Bubalus bubalis) represent a valuable and sometimes vital economic asset in many countries across the world, especially in Asia. In Europe, the rise of mozzarella cheese appreciation led to an important increase in the buffalo population in both countries where breeding this species has a longstanding tradition, such as Italy, and in those who do not, such as Germany (Vidu, 2014). In Romania, although the buffalo livestock has decreased significantly after the fall of the communist regime, along with the general population loss in the animal industry
(Vidu, 2014), the high nutritional value of their milk, especially the high protein and fat content (Barłowska et al., 2011) makes it an important raw material for the cheese industry.

Milk production depends on the morphological health of the udder. The blood flow and vascularisation of the mammary gland is an essential factor of it, with great implications in the pathogenesis and evolution of mammary gland diseases (Popovici et al., 2003). This has been mainly researched in dairy cows, but the economical issue presented by udder pathology in buffalo cows highlights the need for a better understanding of its anatomy. Thomas (2004) 
presents morphological particularities in this species such as a very low cisternal fraction (5\%) of milk retention when compared to cows and longer teat canals, influencing the physiology of milk flow. In view of these differences, the question arises weather the vascular system of the buffalo's udder also has its own particular features or is it similar to that of the dairy cow. This is also important in light of efforts to develop better milking machines tailored to the buffalo's needs. Taking into consideration these aspects, our study focused on the anatomical features of the venous circulatory system of the buffalo cow's mammary gland.

\section{MATERIALS AND METHODS}

The venous vascular system of the mammary gland was studied on 10 udders harvested from 10 commercially slaughtered buffalo cows, 3.5 to 18 years old, in both dry and lactating periods.

The organs were isolated at their base by circular incision of the skin and of the suspensory ligaments, thus cutting the vascular trunks associated with them. The blood and clots were cleaned away from the vessels by rinsing them with a saline solution via a plastic tube adapted to a syringe.

In order to highlight the venous vascularisation and facilitate the examination, a blue dyed latex material was injected through a plastic tube into the lumen of the veins. The tube was attached to the mammary tissue by means of a ligature, and the material was injected slowly and progressively, filling the large veins first, followed by the smaller vessels up to the capillaries. The injected udders were immersed into a $2 \%$ formalin solution for 24 hours, letting the latex harden.

After this interval, each udder was dissected using a standard dissection kit, with the purpose of exposing as much as possible of the venous vascular system of every quarter. The examination of the highlighted vessels was performed both by direct observation and by using an $\mathrm{x} 3$ anatomical magnifying lens. The description of the examined venous systems followed to physiological direction of blood flow, starting from the small venules and ending with the main veins draining the udder.

\section{RESULTS AND DISCUSSION}

The general examination of the highlighted venous system revealed that all the examined udders presented flexuous trajectories of the veins, as well as variations of their diameters, leading to an overall prominent varicose aspect (Fig. 1a). Taking into account the two functional stages (the dry period and the lactating period), we have also remarked an increased caliber of the veins in udders sampled during the active period (Fig. 1a), but no associated morpho-topographical changes were present. Regarding the development ratio, the venous vessels of the caudal quarters were better developed than those of the anterior ones.

Dissection of the teat segment revealed that the venous system macroscopically originates in an anastomotic system of the teat. All samples presented rich networks of venules with circular trajectories merging into superficial venules with ascending trajectory towards the base, where they merged into a circular terminal confluence and this venous circle gave off both the superficial and the deep veins (Fig. 1b)

On the ventral surface of the udder, the superficial veins draining the teats could be observed creating confluences with one another both between homolateral quarters, and between the left and the right side of the udder (Fig. 2a).

Dissection of the mammary parenchyma revealed that there is also an internal network of venous branches ascending toward the base of the quarters, merging and opening into the deep mammary veins (Fig. 2b).

An important finding was that there are common venous trunks for the anterior and caudal quarter of one side of the udder, and there are also perforating vessels which go through the median septum (Fig. 3a), linking the two halves of the udder.

The base of the udder presented a constant great venous circle, formed mainly by the two caudal mammary veins (Fig. 3b). The former drains the blood from the quarters by a system that presented certain variations within the studied sample.

Thus in a majority of 7 out of the 10 buffalo udders examined by us, the teat and parenchyma veins of the caudal quarters merged, forming around each a secondary venous circle, before both of the latter communicated caudally with the basal larger venous circle. (Fig. 3b). Parallel to this, only 5 out of the 10 buffalo udders examined also 
presented secondary venous circles around each anterior quarter (Fig. 4).

Examining the main routes of venous drainage, we have identified, as expected the subcutaneous abdominal vein ( $V$. epigastrica caudalis superficialis), the external pudendal vein (V. pudenda externa) and the internal pudendal veins ( $V$. pudenda interna) through the perineal veins.

The link between the great basal venous circle at the base of the udder and the aforementioned routes was identified as a well-developed trunk emerging from it and forming the two internal pudendal veins (Fig. 1a). Although prevalent, this pattern was missing from 2 of the total examined sample lot.

The particular requirements of milk secretion explain the morphologic complexity of the vascular system of the udder. The variations in vascular girth according to the functional stage of the udder (the dry period and the lactating period) reveal to be common in large ruminants,
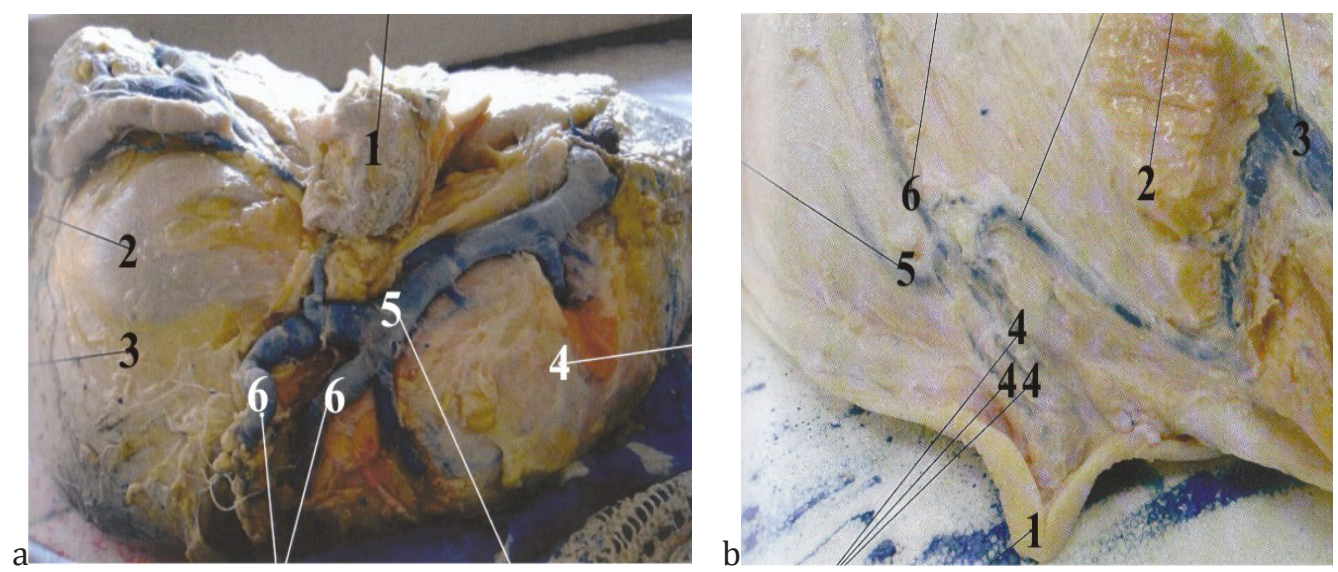

Fig. 1. (a) Common trunk as the origin of the internal pudendal veins - caudal segment of the udder: 1 . Median suspensory ligament, 2. Left supramammary lymph node, 3. Mammary parenchyma of the left caudal quarter; 4. Mammary parenchyma of the right caudal quarter 5. Common trunk of the internal pudendal veins, 6 . Internal pudendal veins. (b) Anastomotic complex of the teat venules: 1. Right anterior teat, 2. Mammary parenchyma of the right anterior quarter, 3. Lateral mammary vein, 4. Veins of the teat anastomotic complex, 5,6,7 basal teat veins.
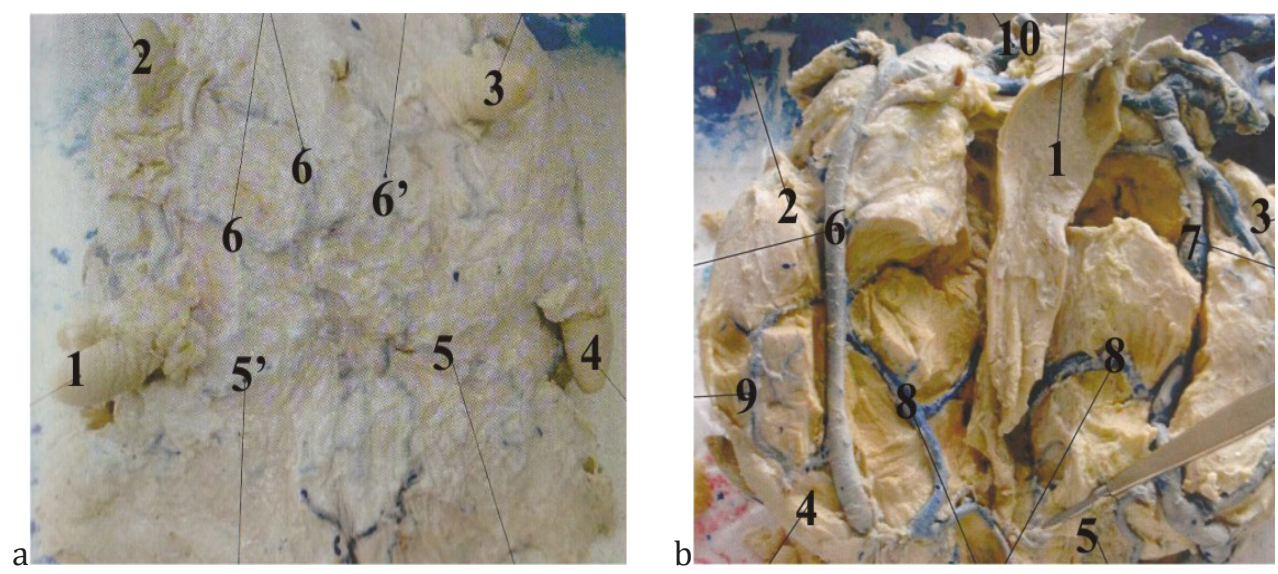

Fig. 2. (a) Aspect of the superficial venous system, ventral side of the udder: 1 . Anterior right teat, 2. Posterior right teat, 3. Posterior left teat, 4. Anterior left teat, 5, 5'. Superficial veinsfor anterior teat's drainage, 6, 6'. Superficial veins for posterior teat's drainage. (b) Venous trunks of the mammary gland: 1. Median suspensory ligament; 2,3. Mammary parenchyma of the right and left posterior quarters, 4,5. Mammary parenchyma of the right and left anterior quarters ; 6. Right cranial mammary vein; 7. Left medial mammary vein; 8 . Deep venous trunks; 9. Basal collateral mammary vein; 10. Basal mammary venous circle. 

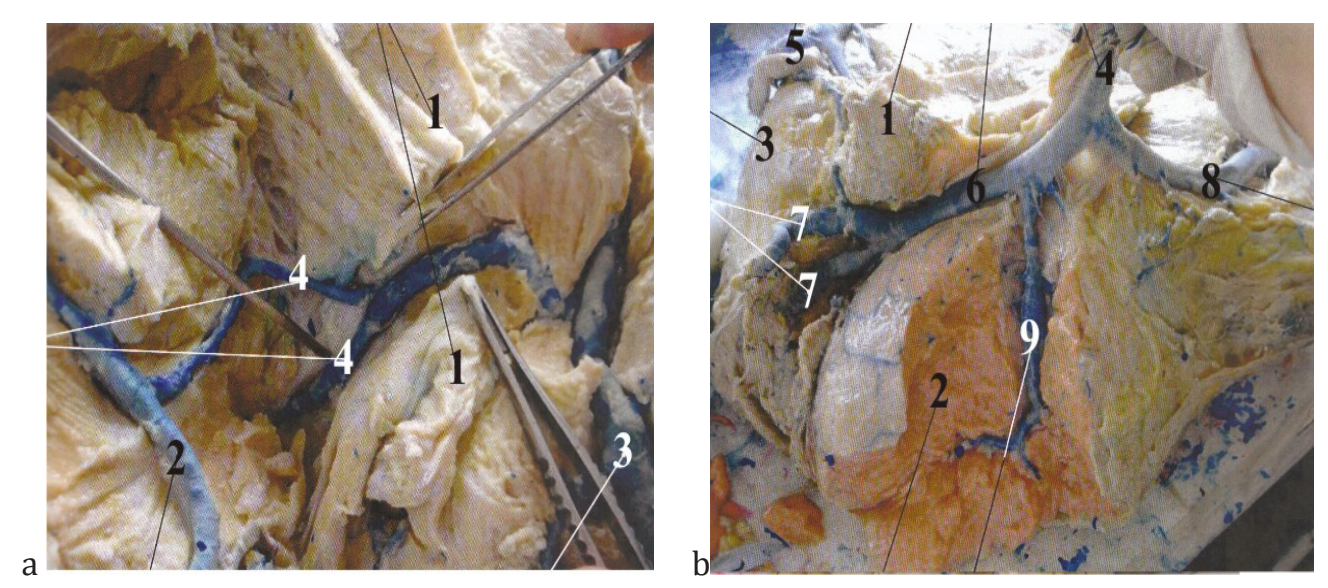

Fig. 3 (a) Perforant venous branches: 1. Median suspensory ligament; 2. Right median mammary vein; 3. Left median mammary vein; 4. Perforant veins. (b) Venous confluences into the right posterior quarter: 1 . Median suspensory ligament; 2 . Mammary parenchyma of the right posterior quarter; 3 . Left supramammary lymph node; 4. Right pudendal vein; 5 . Left pudendal vein; 6 Caudal basal mammary venous circle; 7. Internal pudendal vein; 8. Right cranial mammary vein; 9. Right caudal quarter's venous circle.

as it is a trait also encountered in cows (Socaciu et al., 2007). The fact that the buffalo cow udder has a better developed the venous system in the caudal quarters than in the cranial ones suggest a correlation between levels of quarter blood irrigation and milk-production per quarter, as it has been observed that in dairy cows, also, the caudal quarters yield a better milk production (Tancin et al., 2006).

The general flexuous and varicose aspect of the veins is also a common trait shared with dairy cows, as it has previously been described, without having completely elucidated if it is physiological or if the functional vascular capacity of drainage is surpassed, causing this phenomenon (Constantin et al., 1998; Socaciu et al., 2007; Socaciu, 2009).

The particular aspect of venous topography encountered in the teats concords with literature presentations of dairy cow udder anatomy, as Collin (1976) describes a plexus of venules and a venous circle situated at the base of the teat.

General quarter interdependence remains an important subject today in relation to mastitis management and it has been demonstrated in dairy cows by means such as comparison of milk lymphocyte profile and neutrophil function between infected and non infected quarters (Blagitz et al., 2015). In relation to this, another common trait between buffalo and cow is the venous communication between the left and right halves of the udder (Socaciu et al., 2007; Socaciu,

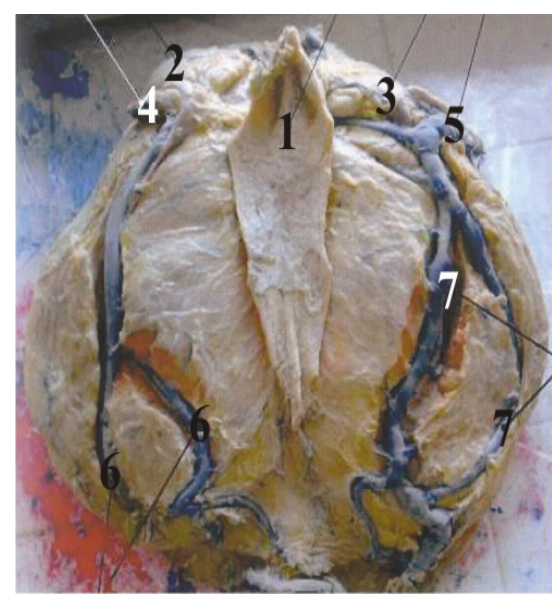

Fig. 4. Bifurcation of the basal venous circle and emerging secondary venous circle: 1 . Median suspensory ligament; 2 . Right supramammary lymph node; 3 . Left supramammary lymph node; 4 . origin of right external pudendal vein; 5 . Origin of left external pudendal vein; 6 . Secondary venous circle of the right anterior quarter; 7 . Secondary venous circle of the left anterior quarter.

2009), contradicting a former standing theory that each quarter has a separated venous system. This feature has also been previously highlighted in cows in the following manner: Larson and Smith (1974) applied antipirine injections in the homolateral quarters, identifying the same substance from the mammary veins of the other half of the udder. 
Having the subcutaneous abdominal vein, the external pudendal vein and the internal pudendal vein is another common trait between buffalo and cow, as the latter benefits from several descriptions of them (Constantinescu, 1982; Popovici et al., 1994; Paştea, 1990; Damian, 2001; Popovici et al., 2003; Chirilean, 2014). The existence of the basal venous circle of the mammary gland, formed the two caudal mammary veins has also been previously mentioned in cows by Ghoshal (1981). The presence of secondary venous circles in the buffalo udder is noticeably inferior to that seen in the cow (Socaciu, 2009).

\section{CONCLUSION}

The venous system of the buffalo cow udder has an overall varicose aspect. The posterior quarters present a superior number of veins than the anterior quarters, correlated to the increased milk production of the former. The superficial mammary veins of one quarter join with the superficial mammary veins of the homolateral quarter. All of the mammary glands have presented perforating veins, which go through the median suspensory ligament. These features are similar to traits identified in dairy cows and need to be taken into consideration in the therapeutic management of mastitis.

Slight variations of the udder's main blood drainage system have been registered: $70 \%$ of the dissected buffalo cow glands contained venous circles inherent to the posterior quarters; $50 \%$ of them contained venous circles inherent to the anterior quarters; and $20 \%$ of the mammary glands of the buffalo cow did not present an internal pudendal venous common trunk. These results can be used for new assessments of pathogen dissemination through the udder vascular system in correlation with Doppler imaging.

\section{REFERENCES}

1. Barłowska J, Szwajkowska M, Litwińczuk Z, Król J (2011). Nutritional Value and Technological Suitability of Milk from Various Animal Species Used for Dairy Production. Comprehensive Reviews in Food Science and Food Safety 10:291-302. doi: 10.1111/j.1541-4337.2011.00163.x
2. Blagitz MG, Souza FN, Batista CF, Diniz SA, Azevedo LFF, Silva MX, Haddad JPA, Heinemann MB, Cerqueira MMOP, Della Libera AMMP (2015). Flow cytometric analysis: Interdependence of healthy and infected udder quarters. Journal of Dairy Science 98(4):2401-2408.

3. Chirilean I (2014). Splanchnologie. AcademicPres, ClujNapoca.

4. Collin B (1976). Atlas d'Anatomie Cheval Bete Bovine Porc Lapin Oiseaux, Universite de Liege, Faculte de Medicine Veterinaire, Laboratoire d'Anatomie, Buxelles.

5. Constantin N, Cotruţ M, Şonea Al (1998). Fiziologia Animalelor Domestice, vol II. Coral Sanivet, București.

6. Constantinescu GhM, Radu C, Palicica R (1982). Anatomia Topografică a Mamiferelor Domestice. Facla, Timişoara.

7. Damian A (2001). Anatomie Comparată. Sistemul Cardiovascular. AcademicPress, Cluj-Napoca.

8. Ghoshal NG, Koch T, Popesko P (1981). The Venous Drainage of the Domestic Animals. W.B. Saunders Company, 130-133.

9. Larson B, Smith V (1974). Lactation - a Comprehensive Treatise, vol I. Academic Press, New York and London.

10. Nanda AS, Nakao T (2003). Role of buffalo in the socioeconomic development of rural Asia: Current status and future prospectus. Anim Sci J 74:443-455. doi: 10.1046/j.1344-3941.2003.00138.x

11. Paștea, E (1990). Anatomia topografică a taurinelor. Ceres, București, 260-263.

12. Popovici I, Damian A, Popovici N (1994). Anatomia Animalelor Domestice. Angiologia. Genesis, Cluj-Napoca.

13. Popovici I, Damian A, Popovici N, Chirilean I (2003). Tratat de Anatomie comparată - Splanchnologie. AcademicPres, Cluj-Napoca.

14. Socaciu A (2009). Cercetări morfologice privind vascularizaţia sanguinăaglandei mamare la rumegătoarele mari. Teză de doctorat. USAMV Cluj-Napoca, România.

15. Socaciu A, Damian A, Chirilean I, Gudea Al, Stan F (2007). Morphological research on the venous vascularisation of the mammary gland in big ruminants. Bulletin USAVM Veterinary Medicine 64(1-2):299-304.

16. Tancin V, Ipema B, Hogewerf P, Macuhova J (2006). Sources of variation in milk flow characteristics at udder and quarter levels. Journal of Dairy Science 89(3):978988.

17. Thomas CS (2004). Milk management of dairy buffaloes. Swedish University of Agricultural Sciences, Uppsala, PhD Diss.

18. Vidu L (2014). Situaţia efectivelor de bivoli la nivel mondial şi la nivel naţional. In : Vidu L, Bota A (coordinators). Particularităţile fenotipice, genotipice şi de creştere ale bivolului indigen, PIM, Iași, Romania. 